\title{
Teaching Compassion in Prison: A Key to Learning
}

\author{
EM STRANG \\ HMP Dumfries (New College Lanarkshire)
}

\begin{abstract}
In a project with long-term prisoners at HMP Dumfries, Scotland, tutors and students explore the notion and application of compassion, focusing in particular on the ways in which understanding compassion enables learning - not just the learning of academic subjects but also of interpersonal skills and emotional intelligence. The project highlights the benefits of teaching a so-called extracurricular subject, at the same time as revealing its centrality to learning in the first place. A lack of adequate teaching time in prison, and the fact that compassion is not considered a core subject in education, are both cited as obstacles in consolidating the work of the project. The benefits of teaching compassion - emotional, intellectual and spiritual - was made clear through written and verbal student feedback. Three short workshops highlighted the enormous potential in developing and establishing compassion as both subject and practice in prison education. It is hoped that practitioners and researchers will support the expansion of this work throughout prisons.
\end{abstract}

Key words: Compassion, holistic prison education, arts-based interventions, spirituality, non-violent communication, rehabilitation, Buddhism

\section{Introduction}

Since I began work as Creative Writing tutor at Her Majesty's Prison (HMP) Dumfries two years ago, my interest in and understanding of compassion has deepened. As a poet, it's always been clear to me that poetry relies on the writer being able to feel her way into the material; to practice empathy by imagining herself into another's world. But the more I thought about compassion and tried to practice it, the more I realised how central it is to learning of all kinds. It seemed to me that a lack of compassion created an obstacle in the path of learning, not just in learning academic disciplines ("I can't do this, I'm rubbish/too stupid/too lazy!") but also in learning interpersonal skills and emotional intelligence.

I decided to organise a project in the prison to explore the notion of compassion, not specifically from the perspective of poetry (though this came into it) but more generally: What is compassion, and how can we learn to be more compassionate to self and other? My aim was to encourage students from all subject areas to get involved in thinking and talking about compassion, in the hope that by practicing it in our daily lives, we might be more open to learning of all kinds. I didn't want to frame it entirely around poetry because I wanted to reach a broader cross-section of students, those who had never attended my classes and had no particular interest in literature or Creative Writing. In the end, however, poetry ended up being a central component of the project, not least because I invited two poets to come in and speak about their relationship to and understanding of compassion.

The project consisted of four sessions with 18 long-term prisoners (at HMP Dumfries, long-term refers to a minimum sentence of four years) over the course of a fortnight. I arranged for three people to visit the prison and offer workshops - two poets, Valerie Gillies and Gerry Loose, via the Scottish Book Trust's Live Literature Fund (http://www.scottishbooktrust.com), and Vérène Nicolas who facilitates workshops in non-violent communication and self-compassion.

\section{What is Compassion?}

I began the project with an introductory session in which we discussed what we thought compassion was and how it manifested in our lives. We discussed definitions of compassion: Empathy; being able to put yourself in someone else's shoes; being open-minded and aware of others' needs; loving ourselves; accepting who we are and who others are, too. Many students were able to recall times when they were shown com- 
passion and also when they were able to be compassionate towards others:

"I remember the time my co-pilot was imploding because his wife had left him - over the phone. He was broken. It's something that happens a lot in here; people on the outside can't bear the sentence any more than we can." ('Co-pilot' is prison slang for 'cell-mate'.)

"And what did you do for him? Were you able to help in some way?"

"Only because I understood where he was at. I knew how he felt. I just listened."

We read a chapter from Marc Barasch's book The Compassionate Life: Walking the Path of Kindness (2014), to look at ways in which people are compassionate to themselves and others. Barasch writes movingly on the events immediately post-9/11, a topic I thought the students would all feel strongly about - and they did. What we came to realise whilst reading and discussing the chapter, was that suffering opens us; that through it we enter a place of vulnerability, somewhere we often choose to suppress or avoid or even actively deny because it's painful; but that it's also a place that paves the way for compassion:

I think the common denominator is the breakdown of your ego to a place of vulnerability. We are brought up to think we all want to be happy and comfortable and up - and that's what we're programmed to go for. And I don't think anybody in their right mind would want to go for the other. But when you have been put there, you become aware that you can relate to others who have been there as well - hearing firemen talking about finding bodies the night before and feeling the pain they were going through. And it wasn't morbid. It was just...connected (Marc Barasch, The Compassionate Life: Walking the Path of Kindness, 2009).

As we read, it became clear that an understanding of the ways in which we are all interconnected is tantamount to an understanding of the roots of compassion. Zen Buddhist monk, Thich Nhat Hanh calls it 'interbeing':

"Interbeing" is a word that is not in the dictionary yet, but if we combine the prefix "inter" with the verb "to be", we have a new verb, "inter-be". If we look into this sheet of paper [...] we can see the sunshine in it. If the sunshine is not there, the forest cannot grow. In fact, nothing can grow. Even we cannot grow without sunshine. And so, we know that the sunshine is also in this sheet of paper. The paper and the sunshine inter-are. And if we continue to look, we can see the logger who cut the tree and brought it to the mill to be transformed into paper. And we see the wheat. We know that the logger cannot exist without his daily bread, and there- fore the wheat that became his bread is also in this sheet of paper. And the logger's father and mother are in it too. When we look in this way, we see that without all of these things, this sheet of paper cannot exist (Melvin McLeod, ed., The Pocket Thich Nhat Hanh, 2012).

Perhaps more importantly, though, it became clear that this understanding isn't something only available to monks and other spiritual practitioners, but something we can all access and exercise.

We took it in turns to read pages of the chapter out loud. At times we found it quite difficult because the material was raw and everyone in the class - of course - knew what it meant to suffer. There was a section early on in the chapter about a fireman, Joseph Bradley, 'a hardhat crane operator who had helped build the World Trade Center when he was twenty-two' (Barasch, 2009), and by the time we got to the end of the page, we had to admit to having lumps in our throats.

Like so many workers at the site, he was overwhelmed by the carnage at the pile, sinking to the curb after his fist night under the savagely bright arc lamps, his head cradled in his hands. "That's when the Salvation Army kids appeared," he remembers, "in their sneakers with their pink hair and their belly buttons showing and bandanas tied around their faces. They came with water and cold towels and took my boots off and put dry socks on my feet.

"And then, when I got to Houston Street, a bunch more of these kids, all pierced and tattooed with multicolored hair, had made a little makeshift stage. They started to cheer as we came out, and that was it for me. I never identified with those people before, and I started crying, and I cried for four blocks. I can't tell you - I was taken so off guard.

"I got home and saw my wife, who asked, 'Joe, are you okay?' 'Sure!' I said. You know the bravado came back. But she said, 'Are you sure? Go look in the mirror.' There I was with my filthy dirty face and just two clean lines down from my eyes."

A community of love was the last thing anyone had expected to find in the mouth of Hell (Barasch, 2009).

\section{The Threat Of Change}

We talked about how 9/11 and its aftermath represented a period of extreme suffering and that extremes like this often seem to bring out the best in humanity - the superficial layer we habitually offer the world is peeled back and we often feel liberated to reveal our true worth and value.

"Not always," one of the students said, " $9 / 11$ is what sparked the whole War on Terror. How enlightened was that?" 
"But Bush and the decision-makers in the White House never personally suffered," I suggested, "They never engaged firsthand with the devastation and trauma of 9/11. They weren't torn open by it. Instead of realising the potential for a compassionate response, they fought back with equal venom."

"Isn't that just a nice, idealistic way of seeing things? People retaliate. That's what we do when we've been hurt."

"Maybe," I said, "But who says it has to be that way? Doesn't it all come down to fear in the end? Isn't it true that for most of us change is threatening and seeing things from a different perspective is frightening sometimes because it challenges our status quo?"

"OK, sure, but how do we actually bring about that change in the world? In other people?"

It's a question that came up a couple of times during the project, but by the time we got to the final session, the students realised they all already knew the answer: change begins with the individual and only then because we choose it. We can only change ourselves and then witness the ways in which this impacts those with whom we inter-are. It's so obvious we often overlook it. Spiritual practitioners and psychologists down the millennia have espoused it, and yet most of us still fail to put into practice the strategies that enable us to do the work of change. And it's hard work, there's no getting around it. It's hard work for those of us not incarcerated; for those of us who are, there are even more challenges to overcome; not least, prison culture's mode of accepted behaviour, which more often than not runs counter to the notion of compassion. In all-male prisons, pathological interpretations of masculinity must also be side-stepped (HMP Dumfries is a men's prison).

Gaining an understanding of this is one thing, "the fundamentals", as one student said; but putting it into daily practice is something else altogether. How do we remember to pause before we act or speak? What does it even mean 'to create a pause'? Luckily, I'd invited Vérène Nicolas, an expert in seeking answers to these questions, and she opened the project's first workshop with a phrase that has stayed with me ever since: Get curious not furious (Marshall Rosenberg, https:// www.cnvc.org/about/marshall-rosenberg.html).

Vérène began by making clear distinctions between universal human needs and the strategies we might employ to fulfill those needs. For example, one of the students suggested 'work' as a universal human need, but we all quickly realised that this wasn't a need, but a strategy to meet deeper needs - self-esteem, for example, or safety, stability, equality. In this way, we were able to see that beneath every action, every choice, there is a human need seeking to be met. If we transfer this understanding to a situation in which conflict arises, a space suddenly opens up: We can now see that on both sides of the conflict, universal human needs are not being met. We were able to see that when we get upset or angry, it's often because a deep need in us isn't being met, and/or a deep need in the other person is also not being met. Even though the psychology of this wasn't new to us, breaking it down in this way helped to open the space up again, to re-define Viktor Frankl's famous words, 'There's a space between stimulus and response.' If we can use this space to see into the needs of self and other, compassion will naturally arise.

\section{The Application of Compassion}

Of course, creating space to open ourselves to compassion sounds great in theory, but in practice it's often much more difficult to achieve. It's something we need to train our minds to accommodate. I decided to test out the theory in a class with short-term prisoners (men sentenced to less than four years) later in the day:

"Imagine you're being bullied by a fellow prisoner because you've got a physical abnormality, say, very short arms. What would you think about the bully and how might you react?"

"Tell him to fuck off. Arsehole...I'd clout him with my very short arms. Ha ha!"

"Would you ever wonder why he was being a bully?"

"Nah. What for? Arseholes like that aren't worth thinking about."

"And have you ever been an arsehole?"

"Oh sure. Who hasn't?"

"And are you not worth thinking about?"

"I didn't say that!" He paused, "Well, I'm not worth thinking about! I'm scum!"

\section{The Workshops}

To begin the process of training the mind to allow compassion to arise, Vérène led an exercise on self-responsibility. The students were asked to remember a recent situation in which someone did something that made them angry or upset. They were then invited to break off into pairs and discuss the following questions, in response to the remembered incident: (i) What thoughts arise? (ii) What do you feel/sense? (iii) What do you need or value? (iv) What could you do now? One student said, 'I've never done this kind of thing before. I wish there was more time to go into it more deeply."

For the project's second workshop, Valerie Gillies 
visited the prison. Valerie is a poet and writer, originally from Ayrshire, and with a close knowledge of the local area, something a number of the students appreciated because many of them come from there. She led a session on natural wells and springs, sharing the pilgrimage she undertook to find them dotted around the country, as well as reading poems from her collection, The Spring Teller (2009). She also brought in photographs of the wells and springs which she passed around, and told tales of the people who had sought them out in times of hardship and ill-health. She said that visiting the wells and springs had been a kind of spiritual journey for her, not just because of the footsteps she was treading in, but because of the clarity and purity of the water she found in these places. In the words of one student:

"Valerie took a simple thing like a well and had us really think, not only about the purity of the water, but also about the fact that you could see through to the bottom of the well - how the water was clear all the way down.

She then led a meditation - we were to focus on a glass of water on the floor - and I was astounded that the deeper I gazed into the water, the more relaxed and content I became."

I'd advertised the project by putting posters up around the prison, and I knew the mention of meditation would be a risk: it would likely mean that some prisoners wouldn't even consider coming along because meditation is seen by many of them as "soft" or "for fairies". However, Mindfulness Meditation had been taught recently at HMP Dumfries, so I knew it wasn't a wholly new concept for everyone. And as it turned out, I needn't have worried:

"Very enjoyable. Surprised at myself. Something I would never have participated in usually."

We concluded the project with a visit from writer and poet, Gerry Loose. Gerry focused on readings from his two most recent books, a poetry collection, Fault Line (2014) and a book of prose about two oakwoods, one in Scotland and one in Finland, An Oakwood Almanac (2015). He also talked frankly about compassion - how he experiences it in his life and how the Buddha teaches it (he's a practicing Buddhist). In particular, he talked about the Buddhist concept of dukkha, the first of the Four Noble Truths: all existence is suffering. Many of the students were already familiar with this, but it was good to be reminded. When we're immersed in our own suffering, it seems so easy to forget that everyone else suffers, too. One of Gerry's poem excerpts touched on compassion for non-humans, for flora and fauna, something that reminded us again of the complexity of inter-being:

\section{7 herons}

in the meadow

horse \& rider

cantering

across the bay

by the old fish yair

Gartness fault

he's been by

with the petrol strimmer

by the fence

a foot wide

by 125 paces

ten species

dead or threshed

could name them all

called friends

am I foolish (Gerry Loose, Fault Line, 2014)

"I thoroughly enjoyed the last of the sessions," one student wrote, "I found a great deal of inspiration listening to Gerry's poetry and writing. I feel that he brought all the sessions together, and now I'm better able to understand the nature of compassion and how the concept relates to literature. A great end to things! Many thanks!"

\section{Student Feedback}

But it wasn't an end to things, it was a beginning. Three months on and we're still talking about it. I think this is partly because the project was so successful - students were enthusiastic and engaged in a way I don't often witness - and partly because it was flawed - there wasn't enough time. It's ironic that there's often not enough time in prison to really explore themes and ideas deeply. The daily routine gets in the way; students come and go (are released); and funding is hard to come by for projects that are deemed extracurricular. Many of the students who attended the project gave me written and verbal feedback, and almost all of them mentioned the paucity of time. Almost all of them wanted more time in Vérène's session to explore the more practical applications of compassion. This was a 3-hour workshop, but we needed at least a full day, if not two, to gain an understanding of needs, how to recognise and then meet them in self and other. If I ran this project again, I'd make sure to factor this in.

Nonetheless, seeing the students come together so well as a group, being mutually supportive and at times 
quite open and vulnerable, even though it was only short-lived, was something to celebrate. It's not often I experience a sense of camaraderie amongst prisoners, at least not in a way that sidesteps the usual banter and machismo. It was good to witness students letting down their guard and I think for them it was a breath of fresh air, a relief, no matter how fleeting. When I suggested this to them afterwards, they said that learning about compassion was relaxing because they didn't have to pretend any more; they realised that everyone's in the same boat, even if the view from the porthole is a bit different.

Self-compassion is something we continue to talk about in class. It's the one aspect of the project that is most frequently revisited. This isn't surprising, I suppose, given that many prisoners struggle with low self-esteem and depression, states of mind that tend more towards self-loathing than self-love. For many of them, it's hard to recognise that if they can't be kind to themselves, they're going to struggle to be genuinely kind to others; that we need to love and nurture ourselves in order to go out into the world with compassion for others. And, most of all, that if we can show compassion for others, we will reinforce the love and understanding we have begun to nurture for ourselves. In other words, compassion is a regenerative circle, not a vicious one: in giving out, we receive something immeasurably valuable back. If there's ever a circle worth being trapped in, it's got to be this one!

A lack of self-compassion often manifests in very obvious ways in my students. For example, in my Creative Writing class, students will sometimes preempt the reading of their poem or short story with a disclaimer: "This is rubbish! You can tell me how rubbish it is when I've finished reading!" Nowadays I invite the whole class to talk about the disclaimer: What's the fear? What need isn't being met here? In what way does this statement set up a vicious circle of low self-esteem and self-righteous ego? How do we apply what we've learnt about compassion to this situation? Obviously, I've had to practice compassion in gauging these kinds of questions, too. The students are now openly enthusiastic about engaging in self-reflective and critical discussions. Interestingly, this has translated over into the classes in which I teach COPI (Community of Philosophical Inquiry) - many of the students in these classes also participated in the project on compassion. At the end of a recent session in which we discussed the philosophical question 'Who Am I?', one student said,

"I love these classes because they make me realise what crazy thoughts I have! I mean, I seem to get stuck in thinking about things in one way only and COPI helps me see that there are lots of different ways of seeing and thinking about things. My head hurts after COPI but in a good way! I feel better somehow."

\section{Conclusion}

The project has taught all of us that compassion is far more than just doing someone a favour or putting our own needs second. In fact, it's taught us that sometimes it's much more important to put our own needs first, in order to be able to extend ourselves for others later. But most of all, it revealed to us that compassion is at the heart of all genuine learning - learning that brings about a change in the individual and therefore a change in the world; that without compassion we remain closed off from opportunities, frightened to try new things and we hide behind habitual ways of seeing and thinking about the world. Compassion opens and enables us; it invites us to embrace a potential we never even knew we had, something that reaches far beyond the few skills learnt during a workshop. If we give ourselves a chance, we can relax into learning a new language or painting a picture without judging it, or writing a story and sharing it without the need to impress or be right or clever or 'good'. In teaching this project, it struck me that Compassion should really be one of the core subjects taught in prisons (and schools for that matter), and that education and human relationships would be all the better for it. Teaching this project has enabled the classroom (and all of us in it) to develop into a space that's much more conducive to learning - of all kinds.

\section{Note}

I'm grateful to the SPS for agreeing to this project, to the Scottish Book Trust for enabling it, and to Vérène Nicolas, Valerie Gillies and Gerry Loose for their passion and participation.

\section{References}

Armstrong, Karen, Twelve Steps to a Compassionate Life (London: Bodley Head, 2011).

Barasch, Marc, The Compassionate Life: Walking the Path of Kindness (San Francisco: Berrett-Koehler, 2009).

Loose, Gerry, Fault Line (Vagabond Voices, 2014). McLeod, Melvin, ed., The Pocket Thich Nhat Hanh

(Boston \& London: Shambhala, 2012). 


\section{Appendix 1}

If you're interested in using the following as a teaching resource, please contact Vérène Nicolas for an explanation of when and how these exercises can be best used (http://www.verenenicolas.org/contact.html).

\section{Exercise on Self Responsibility}

Self-compassion can only happen if we take responsibility for and understand what happens in us when we get upset and react to someone's actions. When we don't take responsibility for the way we react, especially for what happens in our head (i.e. our thoughts), we project, blame, judge and often make things worse.

Self-responsibility means:

We recognise what belongs to us. That's our thoughts (interpretations, evaluations, judgments), our emotional feelings (what's in our heart), our physical sensations (what's in our body), what we want and value (our needs). When we recognise what belongs to us, we can understand why we reacted as we did, can open our heart a little and respond in a way that's easier on ourselves and the other person.

\section{Distinctions:}

- Self-responsibility is not blaming ourselves and making it our fault.

- Recognising what belongs to us does not mean we have to sort things out on our own. We can get help to sort things out.

\section{Exercise:}

1. Remember a recent situation where someone did something and you got angry or upset.

\section{Thinking:}

a. Identify what went through your mind in that moment: what did you think about the other person or about yourself.

b. Notice that and say, "That's what I am thinking about them. That's what I am thinking about myself. That's how I am thinking about what happened. It's not what actually happened. That's me judging and blaming them (or myself). These thoughts are mine. They are my thoughts. There are my judgements."

3. Feeling/Sensing: As you think about this situation,

a. How are you feeling in your heart now (upset, angry, sad...)? Name your feelings. Look at handout "Feelings (emotional states)" to identify your emotional feelings if you are stuck.

b. Notice the feelings and say, "These feelings are mine. These feelings are in me."

c. How are you feeling in your body (heavy, tense, achy, 'butterflies' in the tummy...)? Where in your body are you feeling? Look at handout "Feelings (physical sensations)" to identify your physical feelings if you are stuck.

d. Notice the feelings and say, "These feelings are mine. These feelings are in me. They are in my body."

\section{What you need or value:}

a) In relation to this situation, what is it that you want instead? Deep down, what do you value? What 
are your needs? See handout "Universal Human Needs" to identify your needs if you are stuck.

b) Let yourself feel what you value or need. Try to relax in your body as you do this. Feel what it feels like to want respect, choice, friendship or whatever it is that your needs are in this situation.

5. What could you do now to address your needs and what would you do instead if the same situation happens?

a) Now that you know what your needs are and why you reacted the way you did, is there anything you can do that would give you what you want (i.e. meeting your needs)?

b) Now that you know what your needs are when situations like this happen, what would you like to do next time and make it more likely that your needs will be met?

Copyright: Robert Gonzales, (2011), http://www.living-compassion.org/ 
Appendix II.

Universal Human Needs (without reference to specific people, time, actions, things)

\section{$\underline{\text { Subsistence and Security }}$}

Physical Sustenance

Air

Food

Health

Movement

Physical Safety

Rest / sleep

Shelter

Touch

Water

\section{Security}

Consistency

Order/Structure

Peace (external)

Peace of mind

Protection

Safety (emotional)

Stability

Trusting

$\frac{\text { Freedom }}{\text { Autonomy }}$

Choice

Ease

Independence

Power

Self-responsibility

Space

Spontaneity

\section{Leisure/Relaxation}

Humor

Joy

Play

Pleasure

Rejuvenation

\section{$\underline{\text { Connection }}$}

Affection

Appreciation

Attention

Closeness

Companionship

Harmony

Intimacy

Love

Nurturing

Sexual Expression

Support

Tenderness

Warmth

\section{To Matter}

Acceptance

Care

Compassion

Consideration

Empathy

Kindness

Mutual Recognition

Respect

To be heard, seen

To be known,

understood

To be trusted

Understanding others

\section{Community}

Belonging

Communication

Cooperation

Equality

Inclusion

Mutuality

Participation

Partnership

Self-expression

Sharing

\section{Meaning}

Sense of Self

Authenticity

Competence

Creativity

Dignity

Growth

Healing

Honesty

Integrity

Self-acceptance

Self-care

Self-connection

Self-knowledge

Self-realization

Mattering to myself

Understanding

Awareness

Clarity

Discovery

Learning

Making sense of life

Stimulation

\author{
Meaning \\ Aliveness \\ Challenge \\ Consciousness \\ Contribution \\ Creativity \\ Effectiveness \\ Exploration \\ Integration \\ Purpose
}

\section{Transcendence}

Beauty

Celebration of life

Communion

Faith

Flow

Hope

Inspiration

Mourning

Peace (internal)

Presence

This list builds on Marshall Rosenberg's original needs

list with categories adapted from Manfred Max-Neef.

Neither exhaustive nor definitive, it can be used for

study and for discovery about each person's authentic

experience. 


\section{Appendix III. \\ Feelings}

\section{When Needs are Being Fulfilled}

(emotional states) Feelings that we experience in our emotional body

GLAD, happy, excited, hopeful, joyful, satisfied, encouraged, confident, inspired, relieved, touched, elated

PEACEFUL, calm, content, absorbed, expansive, loving, blissful, satisfied, relaxed

LOVING, warm, affectionate, tender, friendly, sensitive

PLAYFUL, energetic, invigorated, refreshed, stimulated, alive, eager, giddy, adventurous, enthusiastic

RESTED, relaxed, alert, refreshed, energized

THANKFUL, grateful, appreciative
When Needs are Not Being Fulfilled

SAD, lonely, helpless, overwhelmed, dismayed, discouraged, disheartened

SCARED, fearful, terrified, nervous, horrified, anxious, lonely

MAD, angry, aggravated, furious, resentful, disgusted, irritated, annoyed, disappointed

CONFUSED, frustrated, troubled, torn, embarrassed, uneasy, worried, concerned

TIRED, exhausted, fatigued, indifferent, weary, overwhelmed, helpless, heavy

UNCOMFORTABLE, pained, uneasy, hurt, miserable, embarrassed

\section{Feelings}

\section{Expansive}

airy

bubbly

buzzing

light

radiating

relaxed

shimmering

soft

sparkly

warm

\section{(physical sensations) Sensations th
Contracted Burning}

breathless con-

gested

dense

constricted

frozen

heavy

numb

paralysed

sharp

sticky

tense

tight

\section{achy}

flushed

frantic

hot

itchy

quaking

pounding

prickly

pulsing

quivering

sweating

throbbing experience in our physical body.

$\begin{array}{ll}\text { experience in our physical body. } \\ \text { Faint } & \text { Shaky } \\ \text { chills } & \text { fluttery } \\ \text { clammy } & \text { jumpy } \\ \text { cool } & \text { pained } \\ \text { damp } & \text { shuddering } \\ \text { dizzy } & \text { tingly } \\ \text { fuzzy } & \text { trembling } \\ \text { goose-bumpy } & \text { twitching } \\ \text { nauseous } & \text { vibrating } \\ \text { queasy } & \\ \text { wobbly } & \end{array}$

Feelings exist in our bodies, not outside of them. Feelings generally have physical sensations associated with them. The aim is to develop awareness of our feelings, then consciously choose whether or not to express them.

Copyright: Marshall Rosenberg, (2005), http://www.cnvc.org/ and Manfred Max-Neef (1992) 
Em Strang is a poet, teaches Creative Writing, Creative Reading and COPI (Community of Philosophical Inquiry) at HMP Dumfries, and is poetry editor for the Dark Mountain Project. Her first collection of poems, Bird-Woman, will be published in 2016 by Shearsman. She's interested in researching the role and efficacy of the arts in the criminal justice system, and in expanding opportunities for ex-offenders to continue to engage in creative practice. 